\title{
Resolving Rohingya Crisis: Obstacles and Prospects
}

\author{
M. Jashim Uddin \\ Ph.D., An Assistant Professor, \\ Department of Political Science and Sociology, \\ North South University, Dhaka, Bangladesh.
}

\begin{abstract}
Despite having geographical proximity and age-old commercial and cultural ties, Bangladesh and Myanmar have failed to develop a meaningful bilateral relationship due to the Rohingya crisis. Nations have long witnessed numerous crimes against humanity in Rakhine, which brutally killed a lot of Rohingya and forced about 1 million of them to flee from the land they have lived on for centuries. To escape from death and torture they have entered Bangladesh, and are now leading a miserable life. Rohingya are the most persecuted and helpless ethnic minority in today's world. The future of these ill-fated people is truly uncertain. The indifference of the Myanmar government in the matter of the safe repatriation of Rohingya refugees generate doubts and apprehension in the civilized world about whether or not these unwanted people will eventually return to their homeland. Myanmar has always disregarded the Rohingya as an ethnic minority of Myanmar. In addition, the geo-political interests of the large Asian powers, e.g. China and India, military's engagement in politics in Myanmar, and finally, the lack of regular exchange of top leaders and people to people contact between Bangladesh and Myanmar have been the key obstacles for a reliable solution of the Rohingya crisis. Although the neighbors have geo-economic significance and huge potential for cooperation, the analysis of the past record, existing policies and the response of the Myanmar government to the Rohingya crisis reveal that prospects for a safe repatriation of the Rohingya refugees to Rakhine are slim. The study argues that the carrot and stick policies of the major actors including the UN, the Western powers, and China are vital to persuade Myanmar to create a peaceful environment in Rakhine for ensuring the safe repatriation of the refugees and as well as their rights to live with dignity in their own land.
\end{abstract}

Key Words: Rohingya, Genocide, Myanmar, Bangladesh, Repatriation, the Asian Powers, the Western Democracies, Geo-political Interests, Humanity

\section{INTRODUCTION}

Rohingya, the ethnic minority of Rakhine state of Myanmar, are widely recognized as the world's most persecuted and oppressed minority. According to a report published in Prothom Alo, the leading Bengali daily newspaper in Bangladesh, since 25 August of 2017, the Myanmar Army has started creating havoc in order to remove the Rohingya from the map of Rakhine forever. At least 24 thousand Rohingya have lost lives, while the number of rape victims hover around 18 thousand as a result of the hateful and brutal acts of the Myanmar Army (Prothom Alo, 18 August, 2018). Because of the genocide and ethnic cleansing, about a million people have been forced to leave their own land. Rohingya are an ethnic Muslim minority who differ from Myanmar's dominant Buddhist groups ethnically, linguistically, and religiously. A scholar argued that to constitute an ethnic group, six criteria must be met (Brown, 1993). This author argues that Rohingya more or less meet the required criteria to form an ethnic community: the group has a name (Rohingya); they believe in a common ancestry; the group has shared historical memories, they have a shared culture based on common language and religion; the group feels an attachment to a specific land (Arakan/Rakhine); and finally they think of themselves as a group. 
According to the UN Human Rights Commission, Genocide was evident in Rakhine. (The UN Human Rights Commission Report 2018). Renewed violence, including reported rape, murder, and arson in 2017, triggered a massive exodus of Rohingya amid charges of ethnic cleansing against Myanmar's security forces. Nevertheless, the military have denied the charges and counter-claimed that they carried out a campaign to restore peace and stability in the Western region of Myanmar (Albert, Foreign Affairs, 2018), due to which, the Rohingya have been fleeing Myanmar in large numbers to Bangladesh to avoid conflict and persecution.

The facts and evidence of the crime against humanity makes us question whether we are living in the 21st century or in the middle age. Why has the United Nations Security Council (UNSC) in particular failed to take any strong measure, or at least economic sanctions, against the socalled democratic government of Myanmar and its army responsible for the genocide? The Universal Declaration of Human Rights 1948 and the Responsibility to Protect (R2P), that is, the two vital international instruments to protect human rights, have without a doubt failed to protect the ill-fated Rohingya. For its narrow geo-political and strategic interests, it is claimed that China not only justifies the atrocities in Rakhine, but also deters any sanctions against it.

The Rohingya crisis is the key impediment to the extension of bilateral relationship between Bangladesh-Myanmar, two neighbors sharing both land and maritime boundaries. The two countries share $314.40 \mathrm{~km}$ (207.20 land boundary, 68.20 Naf River, and $39.00 \mathrm{~km}$ Maritime up to St. Martin) of common boundary. Myanmar was one of the first neighboring countries to recognize Bangladesh on 13 January 1972 and the countries established their diplomatic missions on 21 March 1972. President Ne Win was the first Asian Head of State to visit independent Bangladesh in April 1974. From Bangladesh side, President Ziaur Rahman paid the first state visit to Myanmar in July 1977. Since then all the heads of the state/government of Bangladesh visited Myanmar. In the recent past, Prime Minister Sheikh Hasina visited Myanmar in December 2011. The return visit of Myanmar President or their prime leader Aung San Suu Kyi to Bangladesh is yet to be realized.

Despite having all these exchanges of high profile visits, time-honored commercial and cultural ties and unlimited potential in reciprocal cooperation in trade and connectivity, the two neighbors failed to build a meaningful bilateral relationship. As of present, the existing trade and people-to-people contact between them are almost nil. Undoubtedly, the Rohingya crisis has had spillover impacts on the other bilateral issues, e.g., leading to, cross border fire, killings, and transnational crimes. The issue has already emerged as a national security concern for Bangladesh. The refugees are a huge burden for a country like Bangladesh where a good number of people still live under poverty line. Although it is noted that the outside sources provide substantial funding for the refugees' food and medicine, Bangladesh still has a heavy weight to bear (Fink, 2009; Solomon, 2017).

The peaceful power transition from a military regime to a democratic government in Myanmar was considered to bring opportunities for developing better relations between Myanmar and the neighbors to solve the Rohingya crisis (Hlaing, 2012). However, the power transform in Myanmar bore witness to one of the most brutal mass killings in history in 2017 (Uddin M. J., 2017). Aung San Suu Kyi and the ruling National League for Democracy (NLD) are concerned with the same issues as their predecessors, the military governments; perceiving the Rohingya issue as deeply security-dominated. Apparently, it seems that the terms humanity, human rights, peace and civil society are absent from the dictionary of Myanmar government. The Myanmar military is involved in conflicts with many other minority groups. Concerning this, Brown noted, "the Burmese military's repression of Karen, Kachin, Naga, and Rohingya insurgents is an ethnic conflict" (Brown, 1993, p. 5). 
Research Objectives and Research Questions:

The objective of this paper is to examine the key obstacles to resolve the Rohingya crisis and identify the potential areas of cooperation between Bangladesh and Myanmar. It also attempts to explore the prospects of a peaceful and lasting solution of Rohingya crisis. This paper attempts to search the answers to the following questions: What are the key reasons behind the Rohingya crisis? What are the obstacles to resolve this crisis? Are Bangladesh and Myanmar geo-economically significant for each other? Do they have potential areas for cooperation? Finally, what are the prospects for a safe repatriation of Rohingya?

This paper consists of six sections including Section one, Introduction. Section Two focuses on the key obstacles to resolving Rohingya crisis including the debate on the ethnic identity of Rohingya. Section Three briefly discusses about the spillover impacts of Rohingya crisis over the other bilateral issues. Section Four explores the geo-political significance of Bangladesh and Myanmar, and the scopes for potential areas of cooperation for mutual benefit. The Final Section provides an analysis of prospects of a peaceful and durable solution of the Rohingya crisis.

\section{KEY OBSTACLES TO RESOLVING ROHINGYA CRISIS}

Rohingya refugee issue has been the prime blockade to building a smooth and meaningful Bangladesh-Myanmar relationship. The refugee issue seems to continue to be an unmanageable bar in establishing any sustainable relations between the two neighbors. In this regard, Christina Fink noted, "Bangladesh has been extremely frustrated by the Burmese regime's refusal to take back all the Rohingya refugees and its continued harsh policies towards the Rohingya." (Fink, 2009). Fink stated this almost one decade ago, but still to this very day, the Myanmar regime continues its harsh policy and shows reluctance to ensure a safe and friendly environment for the safe repatriation of Rohingya. Before analyzing the key obstacles to resolving the crisis, it is necessary to shed light on the origin of Rohingya issue. Who are they? Why do Myanmar government and people hate them so much?

\section{Origin of Rohingya Crisis}

Who are the Rohingya? Are they Myanmar nationals or Bengali Muslims? Are they stateless? The Myanmar government/elites repeatedly alleged that Rohingya are Bengalese while it has been widely recognized and asserted by the eastern and western scholars that the Rohingya are basically Arakanis Muslims inhabiting in Rakhine (new name of Arakan), a geographicallyisolated area in Western Myanmar consisting of coastal plains and a network of streams and rivers, for centuries. It is argued that Rohingya have been living in Rakhine for centuries; some argued since the beginning of the 7th century when Arab Muslim traders settled in Arakan, on the other hand, some other argued that this ethnic minority has been there since 1500 century (Albert, The Rohingya Crisis, 2018).

According to World Bank, more than 78\% of Rohingya are now living below the poverty line (Albert, 2018). They have been denied their civil, political, economic, and social rights in particular since the military took the power in Myanmar in 1962, which were ultimately legalized through the controversial 1982 Citizenship Act (Ahmed I. , 2010). Rohingya Muslims are among the world's most persecuted and ignored minorities. These ill-fated people became stateless in their own land.

\section{Why the Buddhist Majority Hate the Rohingya So Much?}

Why this level of discrimination or hatred against Rohingya Muslims? It is viewed that historically, ethnic Burmese political leaders - whether in government or in opposition parties-have tended to deny or ignore the diversity of interest, background, language and 
concerns of the 'national minorities.' Moreover, Myanmar people rarely recognize such denial as problematic at all. This is evident when considering that the persecution and expulsion of Rohingya Muslims that have been going on at the Bangladesh border received widespread support in Myanmar. According to one scholar, the military drew on popular prejudices that Muslims dominated business and used their profits to build mosques, buy Buddhist wives, and spread Islamic teachings. These negative labels against the Muslim minorities have later fueled anti-Rohingya hate propaganda.

The constitution of Myanmar has become a fiction as it fails to protect the birthrights of its own people. Elites in Myanmar have an extreme negative sensitivity about the ethnic and religious identities, color or appearance of Rohingya and thus deny their birthrights. For instance, in 2009, Ye Myint Aung, Myanmar's then-consul general in Hong Kong, sent a letter to local media and fellow diplomats in which he mentioned that "the Rohingya are as ugly as ogres" and do not share the "fair and soft" skin of other Burmese ethnic groups. Thus, he concluded that Rohingya are neither Myanmar people nor Myanmar's ethnic group but the interlopers in Burma and do not deserve citizenship rights (Tharoor, 2015).

\section{Origin of Rohingya: The Debate}

Myanmar claims that Rohingya are Bengali Muslims who originally came to Rakhine from the Southeast of Bangladesh although they have not provided any concrete evidence to support their claims. But, Rohingya activists counter claim that the Rohingya are descendants of the Muslims settlers who had settled in Arakan long before the British's annexation of Myanmar which is also supported by the historical document by Francis Buchanan in 1799, whereby 'Rooinga' (today's Rohingya) is referred as Muhammedans, the Muslim settlers in Arakan State. In 2013, this author interviewed some Rohingya refugees in two registered and makeshift camps in Teknaf, who claimed that their ancestors lived in Arakan (Rakhine) for centuries.

It is alleged that the British annexed Arakan in 1824, which encouraged a steady movement of population from Bengal or British India to the Arakan. A testimony of this lies in the fact that the population of Maungdaw Township (Rakhine) increased from 18,000 in 1831 to about 100,000 in 1911 (Ahmed I. , 2010). This author argues that even if it was a fact that some people moved from Southern part of the Bengal of British India to Arakan in Myanmar more than 100 years back and settled there as some people moved from Arakan to Bengal and settled in Southern part of today's Bangladesh, does it justify to raise question of their citizenship after a century? During the British era, many people moved from one place to another and lived according to their convenience, so, if question is raised why this particular group of people (Rohingya) should be given citizenship, is it acceptable?

In fact, the fate and political position of the Arakanese Muslims then became closely tied with the British colonial power. When the Japanese Imperial Army who occupied Burma in1942 expelled the British, considerable section of the Arakanese Muslims fled Burma and the Arakan to take shelter in the Bengal of British India. During this period, the political affiliations of the Arakanese became clear; when the Arakanese Buddhists supported the Japanese Imperial Army, the Arakanese Muslims supported the British. Such political affiliation, however, proved fatal for the Arakanese Muslims (Rohingya) later. The affiliation of Rohingya during the British era has been one of the key reasons behind the hatred of Myanmar elite and ordinary people towards the Rohingya. 


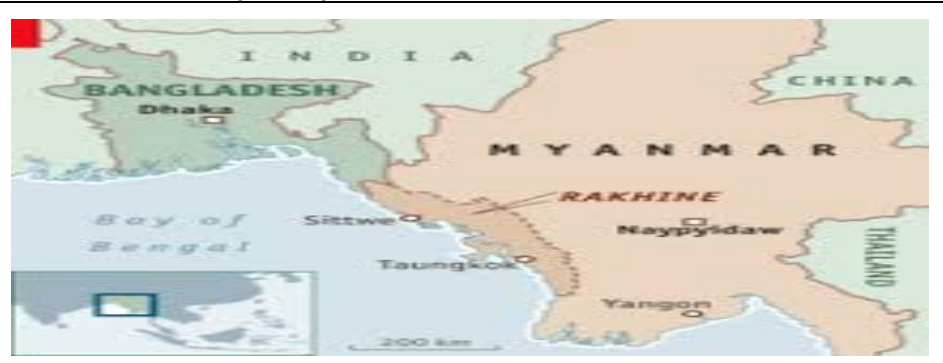

Map 1: Map of Rakhine Myanmar

\section{Obstacles to Resolving Rohingya Crisis \\ Myanmar's Unwillingness to Take Back the Rohingya Refugees}

Myanmar is reluctant to take back the Rohingya refugees to their homeland. Unfortunately, the Myanmar government has refused to accept the identity of Rohingya as an ethnic group of Myanmar. It has always been reluctant to use the term "Rohingya" in any bilateral and multilateral official meetings or dialogues (Marszal, 2016 ). In the Foreign Office Consultation (FOC) of Bangladesh and Myanmar, the latter always demands the Bangladesh delegations not to use the term "Rohingya" but "Bengalese." Hence, the question arises, if the majority of a country does not even accept the existence of a minority group living there for centuries, how could one address and resolve the problem? To justify the ethnic cleansing and expulsion of this large number of ill-fated people, who are not politically organized, the tyrannical Myanmar government wants to destroy their ethnic name. In this regard, the current Secretary General of the UN said while visiting the refugee camps in Cox's Bazaar in July 2018 it was noted that UN and Myanmar officials had major differences over a deal to allow the Rohingya to return. "We disagree with the final status of the Myanmar government. They call them Bengali Muslims, we call them Rohingya. We believe citizenship should be granted, but they are reluctant on this." (Prentis, 2018).

Most of the Bangladeshi people are deeply concerned whether the Rohingya refugees can ever return to their homeland. Although it is difficult to predict, given the strong international pressure on Myanmar, and the bilateral agreement signed by Bangladesh and Myanmar, it is viewed by some that a segment of the Rohingya population may be taken back in the near future (Choudhury, 2018). The visit of a Myanmar delegation led by the Foreign Secretary of Myanmar, Myint Thu, to the Kutupalong Rohingya refugee camp in Cox's Bazaar on 31 October 2018 got attention locally and globally. A group of about 60 Rohingya community leaders met the delegation and raised their apprehensions for a safe repatriation to their homeland and their citizenship rights in Myanmar. Myint Thu listened to the refugees and said that the Myanmar government had verified about 5,000 names of refugees and that repatriation would begin with a first batch of 2,000 returnees in mid-November. Nevertheless, the Rohingya said that they were not very hopeful about the proposed repatriation. Mohib Ullah, A Rohingya, said Rohingya leaders wanted Myanmar to recognize them as an ethnic group with the right to Myanmar citizenship before they return. "When we asked about our citizenship there was no answer," said Abdur Rahim, another Rohingya at the meeting. (Myanmar officials try to convince Rohingya to return, accept ID cards, 2018). However, because of their deep concerns, the UNHCR and Human Rights Watch denounced the recent bilateral decisions by both Bangladesh and Myanmar government to start the proposed repatriation without ensuring the security of the ill-fated refugees in Rakhine.

\section{Geo-political Interests of Big/Regional Powers}

Humanity is crying in Myanmar, the world observes silently. Nonetheless, the UNSC, the apex body of the UN, failed to implement the Declaration of Human Rights in 1948 or Right to Protect (R2P). However, because of the repeated appeal from the Bangladesh government, the UN General Assembly, and conscious world, and the Security Council has eventually 
condemned the Myanmar government for the ongoing ethnic cleansing in Rakhine. Nevertheless, it is not sure whether the Myanmar army really bothers UNSC's concerns. It is well known that this country always has China, one of the permanent members of the UNSC, to hinder any sanctions against it. For its narrow geo-political and strategic interests, China is ready to justify or back the Myanmar army's crime against humanity in Arakan in the name of combating terrorism. China usually seems reluctant to get involved in the internal affairs of another country but Beijing sees Rohingya crisis as an opportunity to regain its lost chance in Myanmar and once again bring the country into its track. At this point question can be raised: What are the specific interests of the Chinese in Rakhine, the coastal region?

In 2004, South Korean company Daewoo discovered 4.5 trillion cubic feet of gas reserves in that coastal area. This has ignited a spark in China to expand its oil sources and extend its influence in the region for immense profits (Heugas, 2017). From 2008, China's state oil company, the "China National Petroleum Cooperation", was granted permission by the Myanmar military government to buy gas from the Shwe reserve that is in Rakhine's offshore basin. The gas was transported from Kyaukpyu to China's Yunnan Province through the Myanmar-China Gas Pipeline. The pipeline, whose construction began in 2010, is said to deliver up to 12 billion $\mathrm{m}^{3}$ of gas per year.

Oil is another of Rakhine's precious natural resource. The Myanmar military agreed to let China work on the construction of a crude oil pipeline along with the gas pipeline. After a two-year delay, the China-Myanmar pipeline began transporting oil from Rakhine's Made Island port towards Yunnan Province in April 2017, four months before the escalation of the crisis in Rakhine. China, being the second largest economy in the world is always looking to expand their market internationally.

As a part of its Belt and Road Initiative (BRI), China wants to make a seaport in Kyaukpyu (Dhaka Tribune, 2017). With the aim of an industrial base the two countries - China and Myanmar- are planning to build up a trade zone in Myanmar to widen up their trade channels. The project will be developed within 1700 hectares. 7.3 billion dollars will be the approximate cost of this project. Three Chinese and one Thai company are willing to take $70-85 \%$ of this development and rest will be taken and monitored by the Myanmar government.

A port already exists in that site. It is used mostly to export local goods and the capacity is relatively very small. Once this becomes a "deep seaport", and it is developed according to the plans, then its facilities will increase (Gupta, 2017). The annual capacity will be of 7.8 million tons of bulk cargo and 4.9 million of TUE (standard unit of measuring the capacity of container ships). The port will be an addition to the marine infrastructure for China's Belt and Road Initiative (BRI) and will connect Chittagong in Bangladesh, Gwadar in Pakistan, and Colombo in Sri Lanka (Islam, The Daily Star, 2017). This will also presumably become one of the busiest shipping routes in the entire world, by helping China's oil imports and also by connecting China to almost all the countries in the world (The Star Online, 2017).

This ambitious project also known as One Belt One Road (OBOR) project, if executed successfully, will also enhance new trade routes and networks from China to the European, African and Asian continents. China currently carries most of its import throughout the Malacca Strait. However, Malacca Strait is also a prime target for piracy. China fears the possibility of a naval blockade happening in the event of a conflict. It would be catastrophic for China, as $80 \%$ of its oil imports from the Middle East are transported through the strait. With a pipeline crossing Rakhine, oil from Abu Dhabi, Iraq, Iran and Saudi Arabia would reach China more safely. 
China plans to invest US $\$ 10$ billion into the Kyaukpyu Special Economic Zone (SEZ), in addition to the estimated US $\$ 2.5$ billion invested in the China-Myanmar oil and gas pipeline projects. The dual pipelines known as the "Thelong Myanmar - China Oil and Gas Pipeline Project", runs up to $771 \mathrm{~km}$ from Rakhine to southwestern China. The deep-sea port and an industrial park around the city of Kyaukpyu in Rakhine, as planned out will have an immense impact upon the countries. It aims to turn the area, which extends over $17 \mathrm{~km}^{2}$, into a maritime economic hub. All this will have an immeasurable positive effect on the economy of China. That is why they have decided to take a tough stand with the Myanmar government and said they have a right to protect their sovereignty and combat terrorism. When the Western democracies particularly the UK, the USA and France insisted to ensure a "transparent investigation" by the UN into the human rights violations in Rakhine, Beijing said it was against any such investigation.

On the other hand, the role of India, the largest democracy, in this crisis is also not desired. K Yhome of the Observer Research Foundation said that India consider the Rohingya crisis as an internal affair of Myanmar (Ja, 2017). According to one report, "Myanmar is rich in natural resources and New Delhi and Beijing are already locked in competition in exploiting its petro resources" (Joshi, 2017). The two projects of utmost importance to China and India are located in the Rakhine State where the helpless Rohingya lived. Myanmar serves as the central hub for India's Act East Policy (AEP), which is implemented as a strategy to cultivate extensive economic relations with the nations of South East Asia. India's intention is the "Tri lateral Highway" which will link India, Myanmar and Thailand. It is budgeted around $1200 \mathrm{Cr}$ rupees and will include construction of over 69 bridges on the Tamu-Kyigone-Kaluwa section (Thiha, 2018). Once this is completed, the three countries will be connected from Manipur in India to Mae Sot in Thailand via Myanmar. This connectivity will greatly improve communications and tourism and will have significant impact on the Indian economy provided the highway have possibilities for further enhancements into countries like Vietnam, Cambodia and Laos.

\section{Myanmar Military's Involvedness in Politics and Grip on Power}

The UN Secretary-General Antonio Guterres has claimed that Rohingya persecution is continuing under the auspices of Myanmar Army, which remains the main obstacle to ending the Rohingya refugee crisis (Prentis, 2018). He accused the military who is mainly still in charge for genocide and ethnic cleansing in Rakhine and urged the international community to put pressure on the military in order to make things to change. He noted, "It is crucial the government in Myanmar and more importantly the military fully understands that these people have the right to go back and live in Myanmar without discrimination." When pushed if this included Aung San Suu Kyi, Guterres said "yes, but I am not a judge. It is clear the military is still in charge."

An Independent international fact-finding mission on Myanmar in a report released on 27 August 2018 said there was evidence indicating "genocidal intent" by the Myanmar military against Rohingya minority and that crime against humanity and war crimes appear to have been committed. The UN investigators also named six top army generals, including the commander-in-chief of the Myanmar Army, whom they said must be investigated and prosecuted for the above charges. Bachelet, the UN Human Rights commissioner, welcomed a decision by the Pre-Trial Chamber of the International Criminal Court's (ICC) finding that it has jurisdiction over the alleged deportations of Rohingya from Myanmar to Bangladesh as a possible crime against humanity.

\section{Lack of Visit of Top Leaders and People to People Contact}

For a peaceful solution of the Rohingya crisis, a constructive engagement between Bangladesh and Myanmar is vital. With mutual suspicion, dialogues, whatever the numbers they shall not 
bring light at the end of the tunnel. Hence, it is observed that a major hindrance for a constructive engagement is the lack of trust and confidence in each other between the governments, thus resulting in the lack of exchange of top leaders and lack of people-to-people contact. Mutual visits of top leaders can bring opportunities for the nations, reduce suspicion, and build confidence. People to people contact can help the neighbors know each other better. Interactions between the ordinary people of both countries, such as exchange of students programs, cultural programs, tourists can help to reduce suspicion. A lingering trust deficit is overshadowing a positive dialogue mind-set and hindering institutional collaboration among pertinent bodies of different ministries of the two countries. Due to the lack of regular interactions and joint ventures, both countries have failed to curb illicit networks in the border areas and other transnational security problems.

Amongst all the reasons behind, some of the key obstacles to bringing a permanent solution to the Rohingya crisis are analyzed in this paper. The removal of these obstacles or the strategies to resolve this long-standing conflict remain as a prime concern. However, before focusing on the potential areas of cooperation and examining the prospects of a durable solution of the crisis, it is important to consider the spillover impacts of this refugee crisis on the other bilateral issues between Bangladesh and Myanmar.

\section{SPILLOVER IMPACT OF ROHINGYA CRISIS ON CONNECTIVITY AND TRADE Lack of Connectivity}

Lack of connectivity is one of the key obstacles to construct a better relation between Bangladesh and Myanmar. The stability and security of Teknaf and Maungdaw, the two bordering cities of Bangladesh and Myanmar, is affected by the influx of Rohingya from Myanmar to Bangladesh. The security in the border areas is prerequisite for enhancing trade and connectivity between the countries (Syeda NaushinParnini, 2012). In the era of globalization, when nations are reaping benefit from their relations even though they are far from each other, these two close neighbors do not have even road links or sea links for trade, commerce and people-to-people movement. Historically these links were there, but fell into disuse for decades. In 2007, Bangladesh signed an agreement with Myanmar to develop a road from Cox's Bazar to Kyauktow.

Bangladesh proposed Myanmar to build 25-kilometer road (2 km in Bangladesh and $23 \mathrm{~km}$ in Myanmar) at its own cost. The main objective was to construct $2 \mathrm{~km}$ long Balukhali-Gundum road within Bangladesh and $23 \mathrm{~km}$ long Gundum-Bawlibazar road within Myanmar for establishing direct road link between the two countries. However, Myanmar did not show any interest later (Uddin M. J., 2014). The Bangladesh government is also interested in setting up a railway network between Kunming city in Yunun province and Chittagong via Myanmar. A 130 $\mathrm{km}$ railway track will be laid from Dohazari of Bangladesh to Gundum in the Arakan state of Myanmar via Ramu of Cox's Bazar. The route would also strengthen connectivity between Bangladesh and Myanmar. Nevertheless, Myanmar has fear that the Rohingya insurgency problem might escalate if any direct road link is to be established between the two countries.

\section{Insignificant Bilateral Trade}

The Bangladesh-Myanmar bilateral trade figure is insignificant compared to Bangladesh's trade with other neighboring countries. The bilateral trade reached around $\$ 100$ million in FY 2012-13. That year, Bangladesh's exports stood worth of $\$ 13.67$ million and imports $\$ 84$ million. The balance of trade was heavily in favor of Myanmar. However, in FY 2015-16, Bangladesh's export increased to $\$ 38.23$ million while imported goods from Myanmar was worth US\$ 38.10 million in the same fiscal year. ' (Bangladesh Export Promotion Bureau, FY 2015-2016). Due to lack of confidence and connectivity, the bilateral trade is insignificant. 
Fig 1: Export from Bangladesh to Myanmar from fiscal year 2011-12 to 2015-16

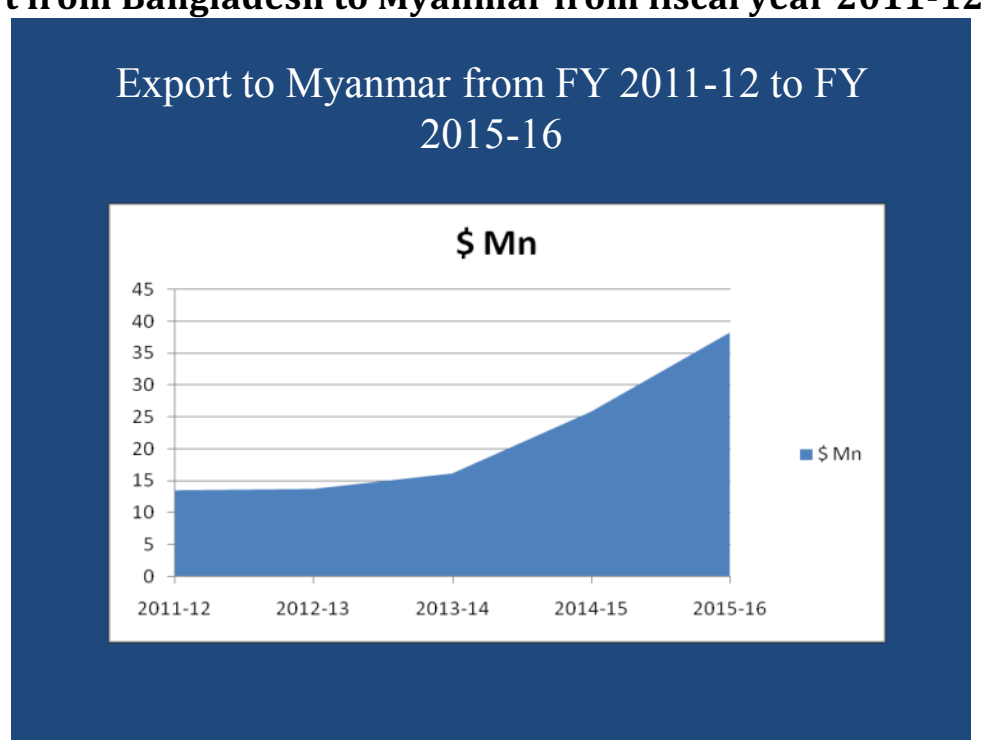

Source: Bangladesh Export Promotion Bureau

Fig 2. Trade between Bangladesh and Myanmar in FY 2015-16

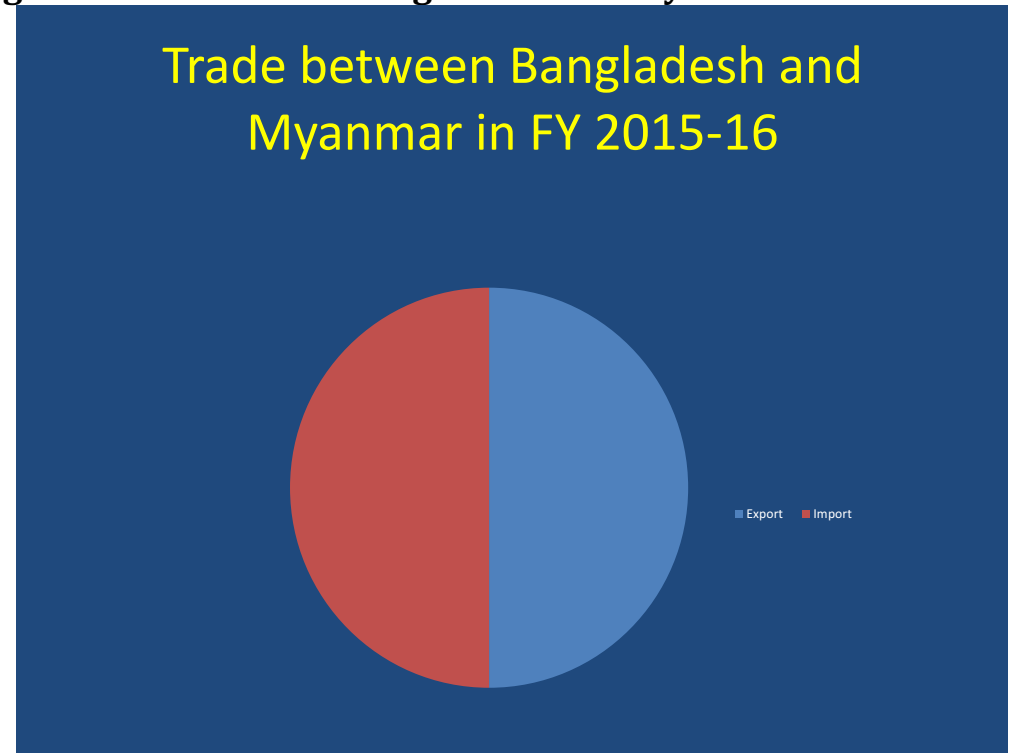

Source: Bangladesh Export Promotion Bureau

\section{GEO-POLITICAL SIGNIFICANCE AND POTENTIAL AREAS OF COOPERATION FOR MUTUAL BENEFIT FOR BANGLADESH AND MYANMAR}

\section{Are these Neighbors Significant for Each Other?}

Both geo-strategic and geo-economics perspectives justify the necessity of strong BangladeshMyanmar relations. Friends or allies may be changed but not neighbors. They are linked by history, culture and geography and must live and prosper together. Any incident in one country can definitely have spillover impacts on neighbors (sheikh, 1998).

Importance of Myanmar to Bangladesh is: i) Myanmar, the largest country of mainland Southeast Asia, with an area of some 678,500 kilometers lies at the juncture of three regions within Asia: East, Southeast, and South Asia. It occupies a critical geostrategic position between the two Asian Giants China and India. ii) It is located in a region, which has experienced tremendous economic growth over the last few decades. The huge reserves of natural resources and its geostrategic location between South and Southeast Asia suggest that it has the potential to be a major Southeast Asian player (Morten B. Pedersen, 2000). iii) Myanmar can be the potential gateway for an alternative land route opening towards China and 
Southeast Asia for Bangladesh boosting her trade and connectivity. The geopolitical importance of Bangladesh will remain intact to India, China and other South Asian countries if it can become a bridge between South Asia and the South East Asian Countries. iv) Bangladesh currently produces enough food grains for its people; yet, it needs to protect itself against drought, flood or other natural disasters. By 2025, its population will be over 200 million. Myanmar is blessed with huge natural resources and can be a more reliable source for food grain than any other country (Ethirajan, 2012). v) Myanmar has now become a magnet for foreign investment. A report by the McKinsey Global Institute estimated that Myanmar could attract as much as $\$ 100$ billion in FDI over the next two decades (Wilson K. , 2013).

On the other hand, significance of Bangladesh to Myanmar is: i) Bangladesh can also be a gateway for Myanmar to connect to eastern India and other parts of South Asia. Certainly, bridging Bangladesh will increase Myanmar's importance to China and ASEAN countries for enhancing connectivity. ii) Chittagong-Kunming connectivity could bring enormous opportunities for Myanmar especially earning huge transshipment fee from the countries of the three sub-regions of Asia (East, South and Southeast Asia). iii) With the rise of middle class, Bangladesh can become a potential market for Myanmar. (Rahman, Ashfaqur Rahman, "Bangladesh-Myanmar Relation Centre for Foreign Affairs Studies (CFAS), Ashfaqur Rahman, "Bangladesh-Myanmar Relations: The Economic Dimension," Centre for Foreign Affairs Studies (CFAS), available at http://www.muslimpo 2014).

iv) A peaceful solution of the refugee problem is vital for the growth of Rakhine state. Hence, Bangladesh's cooperation is crucial for Myanmar. v) Bangladesh has a global reputation for peacekeeping and microcredit activities. Myanmar can receive cooperation and gain experience from its neighbor in the respective fields, in particular, Bangladesh can help promote human resource development in backward areas like Rakhine state.

\section{Potential Areas of Cooperation for Mutual Benefits}

For reducing misperceptions and building confidence, Bangladesh and Myanmar can extend cooperation in some potential areas. Several areas have been identified in this section for cooperation:

\section{Cooperation in Energy Sector between Neighbors}

Bangladesh is an energy hungry country whereas Myanmar is rich in it. There are prospects of cooperation in the energy sector through importing gas from Myanmar. Applying the buyback policy, a joint venture can be initiated in the border district of Bangladesh as such by using Myanmar's gas; Bangladesh can produce urea fertilizer and export to Myanmar for its agricultural needs. Bangladesh has already showed interests for importing gas, but Myanmar has been reluctant as it always said that after meeting their domestic needs, if there were surplus, then it would export to Bangladesh. However, in September 2010, it was announced that the two countries would sign a MoU to build two dams in Arakan state. The dams would supply 575 MW to Cox Bazaar. However, there is no concrete timeframe and advancement for the project.

\section{Cooperation in Promoting Human Resources}

The neighbors can cooperate on various socio-economic issues including microcredit, education and women empowerment. Bangladesh is proud to have two globally reputed microcredit organizations like Grameen Bank and BRAC. Model of Grameen Bank is adapted by other countries. BRAC, on the other hand, has experience to expand its activities in many countries in the world including several African countries and Afghanistan. It has already started activities in Myanmar in a small scale. It can play significant role for promoting human resources in the remote or backward areas like the Rakhine state in Myanmar. Vocational 
training could be another area, where they can help Myanmar. If the Myanmar government shows interest, Bangladesh government can proceed in this regard. ${ }^{\mathrm{ii}}$

\section{People to People Contact}

Despite being neighbors, both nations have hardly known about each other's culture, food habits, geography, and famous places. Therefore, people-to-people contact is the key for attaining a new height in Bangladesh-Myanmar relations. It can be attained through tourism, student exchange, organizing sports events etc. (Rahman, Changing Contours of BangladeshMyanmar relations , 2016). Every year almost 3 million tourists from all over the world visit Myanmar as it has many attractive tourist spots. ${ }^{i i i}$ On the other hand, every year, the number of Bangladeshi tourists visiting Thailand and Malaysia is about six hundred thousand, but the number of tourists visiting Myanmar is almost nil. Both countries have several religious and historic places to explore and have vast opportunities for promotion of tourism. Student exchange, on the other hand, can be another way to boost up the idea of people-to-people contact. For boosting student exchange, the Ministry of Health of the Bangladesh government planned in October 2013 to provide financial support/scholarships to five Myanmar students who are interested in studying medical science in Bangladesh. ${ }^{\text {iv }}$

\section{Cooperation on Peacebuilding Training}

Bangladesh is highly experienced and globally reputed in providing training for peace support operations and the country has been the second largest contributor at UN peace missions. Therefore, Myanmar can be benefitted from sending its personnel to Bangladesh to be trained in those. The Bangladesh Institute of Peace Support Operation Training (BIPSOT) can be the leading institute for providing necessary education to those officials.

\section{Chittagong-Kunming Connectivity via Myanmar}

Chittagong-Kunming connectivity including highway and railroad among Bangladesh, Myanmar, and China is imperative for greater cooperation. The connectivity can bring enormous opportunities not only for the above three countries but also for the whole region. (Uddin M. J., 2014) A direct road link would help lessen transportation cost and increase smoother and timely delivery of products in trade. The traffic of transportation from Bangladesh to China through Myanmar can provide the country with a huge amount of transit and transshipment fees and other associated revenues. Through this road link, a corridor can be extended up to other ASEAN nations.

\section{Investment in Myanmar}

It is a fact that Myanmar is more resourceful and endowed with more natural resources compared to Bangladesh. Myanmar is almost 6 times larger than Bangladesh. But because of the policy of Myanmar, the resources have remained largely unexplored. If the country had maintained the open door policy to the Bangladeshi people, it could be benefited economically. Bangladeshi entrepreneurs are interested to invest in Myanmar, particularly in agroprocessing industries.

\section{CONCLUDING REMARKS}

Despite having geo-economic significance and potential areas for cooperation, the immediate neighbors have failed to advance a meaningful bilateral relationship due to the Rohingya crisis. An objective analysis of the obstacles to the resolution of the Rohingya crisis reveals that the narrow perspectives and existing policies of the Myanmar government concerning Rohingya ethnic minority clearly deny human rights, disregard historical facts and contradict the diverse culture of the society. Perhaps it would not be inappropriate to raise the following questions: Does the country have a civil society or human rights activists? How does a democracy tolerate 
these atrocities in this $21^{\text {st }}$ century? Is it really a democracy? It is evident that the military of Myanmar is responsible for the genocide and ethnic cleansing. The UN Human Rights Commission formally accused the higher military officials including the Army Chief for crimes against humanity. Simultaneously, the role of Aung San Suu Kyi and her democratically elected government have been highly criticized for not safeguarding the Rohingya minority. Thus, they cannot deny the responsibility of genocide, and must be brought to International Criminal Court (ICC). The government of Myanmar is an ideal example in today's world of a tyranny of brutal majority elected democratically.

Myanmar is reluctant to start the repatriation process of the refugee although it signed an agreement with Bangladesh in January 2018. Despite having geo-strategic and geo-political significance and potentials for cooperation in different areas, because of the stereotypical mindset and lack of political will of the Myanmar government, prospects for a peaceful and lasting solution of the Rohingya crisis look bleak. Realization of the Myanmar government of their atrocities and brutalities is so far unlikely. In addition, Chinese support to this country will remain for its greater geo-political and geo-economic interests. China seems willing to gain its strategic and economic interests at the cost of humanity. Nevertheless, in reality, Chinese role will remain crucial in managing the crisis as it has strong economic engagement with both Bangladesh and Myanmar. It has "carrot and stick" to control Myanmar. It is strongly viewed that China was and has been behind the screen to push Myanmar and Bangladesh to sign the bilateral agreement in January 2018. Nonetheless, by doing this China might try to shift the attention from multilateral approach to bilateral one that ultimately China thinks, will reduce international pressure on Myanmar and China.

How effective is or would be the current bilateral mechanism to resolve this ethnic conflict is a great concern. With analyzing the past historical record, bilateral agreements signed in different times in history and their outcomes until now, it can be argued that without creating mounting pressure on Myanmar including strong economic sanctions on the Myanmar government and Myanmar Army in particular, there will be no permanent solution to the Rohingya crisis.

While the Western World particularly the US, Canada and EU have severely criticized the Myanmar government, there have been no major sanctions placed on Myanmar compelling the government to ensure human rights of the Rohingya minority including their citizenship right and a safe return to their homeland. Nevertheless, it is argued that while the Western World time to time, takes some measures to warn the Myanmar government, the Western tourists turn away from Myanmar; Myanmar continues to receive firm economic support from its Asian partners, led by China and Japan, but also including Thailand, India, Singapore, and others. Whether they are acting purely out of economic self-interest or for geopolitical reasons, or both, these regional governments are giving Myanmar crucial support in this stressful period (Wolf, n.d.). Under this milieu, the Western democracies have to play a critical role in resolving the Rohingya crisis (an Asian crisis) in 'the Asian Century'.

\footnotetext{
i Bangladesh Export Promotion Bureau, FY 2015-2016.

ii It is a note here that in an Informal Track II dialogue between Bangladesh Institute of International and Strategic Studies (BIISS) and Myanmar ISIS (MISIS) held in Singapore on 21 January 2014, the delegation from MISIS requested the Bangladeshi delegation to help Myanmar promote human resource development particularly in the backward regions of the country. The author was involved in the dialogue.

iii Information collected from the Southeast Asian Desk, Ministry of Foreign Affairs, Bangladesh Government on 25 March 2014.

iv Ibid
} 


\section{BIBLIOGRAPHY}

২৪ হাজার রোহিঙ্গাকে হত্যা, ধর্ষণের শিকার ১৮ হাজার (24 thousand Rohingya Killed while 18 thousand victims of Rape). (2018, August 18). Prothom Alo.

Ahmed, I. (2010). The Plight of the Stateless Rohingyas: Responses of the State, Society \& the International Community . Dhaka: University Press Limited (UPL).

Albert, E. (2018, April 20). Foreign Affairs. Retrieved from https://www.cfr.org/backgrounder/rohingya-crisis

Albert, E. (2018, April 20). The Rohingya Crisis. Retrieved September 25, 2018, from Council on Foreign Relations: http://www.cfr.org/burmamyanmar/rohingya-migrant-crisis/p36651

Brown, M. E. (1993). Causes and Implications of Ethnic Conflict. In M. E. Brown, Ethnic Conflict and International Security (pp. 4-5). London: Princeton University Press.

Choudhury, A. (2018, April 05). Will Rohingya Refugees Ever Be Repatriated to Myanmar? Retrieved October 25, 2018, from The Diplomat: https://thediplomat.com/2018/04/will-rohingya-refugees-ever-be-repatriated-to-myanmar/

Ethirajan, A. (2012, Dember 18). Bangladesh bids to boost trade with Burma. BBC News.

Fink, C. (2009). Living Silence in Burma: Surviving Under Military Rule. New York: Zed Books ltd.

Fink, C. (2009). Living Silence in Burma: Surviving Under Military Rule. New York: Zed Books ltd. New York: Zed Books ltd. Hlaing, K. Y. (2012, Agust). Understanding Recent Political Change in Myanmar. A Journal of International and Strategic Affairs, 32(2).

Ja, P. (2017, February 3). India's Rohingya dilemma: A clash of interests and values. Hindustan Times.

Marszal, A. (2016, May 6). New Delhi Aung San Suu Kyi's government rejects term 'Rohingya'. Retrieved September 15, 2018, from Telegraph: https://www.telegraph.co.uk/news/2016/05/06/aung-san-suu-kyis-government-rejects-termrohingya/

Morten B. Pedersen, E. R. (2000). Morten B. Pedersen, Emily Rudla Burma Myanmar: Strong Regime Weak State. London: C. Hurst \& Co. Ltd.

Myanmar officials try to convince Rohingya to return, accept ID cards. (2018, November 1). Retrieved November 1, 2018, from The Daily Star: https://www.thedailystar.net/rohingya-crisis/news/myanmar-officials-try-convince-rohingyareturn-accept-id-cards-1654732

Myanmar officials try to convince Rohingya to return, accept ID cards. (2018, November 1). Retrieved November 1, 2018, from Rohingya Crisis: https://www.thedailystar.net/rohingya-crisis/news/myanmar-officials-try-convince-rohingyareturn-accept-id-cards-1654732

Prentis, J. (2018, July 3). UN chief: military grip on power key obstacle in resolving Rohingya crisis. Retrieved September 20, 2018, from The National: https://www.thenational.ae/world/asia/un-chief-military-grip-on-power-key-obstacle-inresolving-rohingya-crisis-1.746664

Rahman, A. (2016, March 20). Changing Contours of Bangladesh-Myanmar relations . The Daily Star.

Rahman, A. (Ashfaqur Rahman, "Bangladesh-Myanmar Relations: The Economic Dimension," Centre for Foreign Affairs Studies (CFAS), available at http://www.muslimpo 2014). Ashfaqur Rahman, "Bangladesh-Myanmar Relation Centre for Foreign Affairs Studies (CFAS). Retrieved September 10, 2016, from Bangladesh-Myanmar Relations: The Economic Dimension: http://www.muslimpopulation.com/pdf/Bangladesh_myanmar_relation.pdf

Sassen, S. (2017). land grabs and the Rohingya crisis. The gaurdian.

sheikh, Y. A. (1998). Yunus Ali sheikh, "Bangladesh-Myanmar Relations: Making The Best of Proximity”. biiss journal, Vol. 19(4).

Slodkowski, A. (2018). U.S. aid chief reaffirms commitment to Myanmar amid Rohingya crisis. Retures.

Solomon, F. (2017, November 3). Myanmar's Crisis, Bangladesh's Burden: Among the Rohingya Refugees Waiting for a Miracle. Retrieved October 25, 2018, from Time: Feliz Solomon Myanmar's Crisis, Bangladesh's Burden: Among the Rohing http://time.com/5031342/bangladesh-myanmar-rohingya-refugee-crisis/

Syeda NaushinParnini, V. 5. (2012). Non-Traditional Security and Problems of Rohingya across Bangladesh-Myanmar Borders. British Journal of Arts and Social Sciences, 5.

Tharoor, I. (2015, February 13). Why does this Buddhist-majority nation hate these Muslims so much?

Uddin, M. H. (2012). “Bar Between Brothers: Rohingya-Issue in Bangladesh-Myanmar Relations”. Dhaka: ICDR.

Uddin, M. J. (2014). Prospects for Attaining a New Height in Bangladesh-Myanmar Relations: Bangladesh Perspective. biiss journal, 22.

Uddin, M. J. (2017, October 22). R2P and Response from ASEAN. The New Age.

Wilson, K. (2013, October 4 ). Asia Weekly: Myanmar poised for FDI take off. Retrieved September 25, 2018, from China Daily Asia: Karl Wilson, "Asia Weekly: Myanmar poised for FDI take off", China Daihttp://www.chinadailyasia.com/business/2013-10/04/content_15091101.html.

Wolf, S. O. (n.d.). Retrieved from https://www.dw.com/en/myanmars-rohingya-conflict-more-economic-thanreligious/a-18496206 